\title{
A Critical Review on the Ubiquitous Role of Filamentous Fungi in Pollution Mitigation
}

\author{
Jorge A. Ferreira ${ }^{1}$ - Sunita Varjani ${ }^{2} \cdot$ Mohammad J. Taherzadeh $^{1}$ (D)
}

Published online: 20 July 2020

(C) The Author(s) 2020

\begin{abstract}
Propose of Review Anthropogenic activities are saturating wastewater treatment plants and the environment with an increasing range of organic and inorganic compounds, impairing ecosystems and health. Filamentous fungi, with characteristic filamentous growth, array of extracellular and intracellular enzymes, production of surfactants, cell wall biosorption properties, and symbiotic momentum, can contribute to a paradigm shift on the perception of anthropogenic pollution. This review provides a critical analysis of the main bottlenecks for feasible filamentous fungus-including processes and proposes a holistic approach for pollution mitigation using filamentous fungi.

Recent Findings Filamentous fungi can convert ordinary sidestreams into, e.g., feed proteins and biofuels. Economic and environmental studies support integration in established processes. Intersectoral initiatives, and economic and environmental studies, need to be motivated to increase the range of processes. Although massively studied, the transfer of fungal processes for the removal of micropollutants into real matrices is difficult. It needs to be supported by omics technologies for the study of microbial networks, and by efficient analytical techniques to clarify detoxification potential. The area can benefit from knowledge integration from fungal growth in ordinary sidestreams, and from economic and environmental studies.

Summary The interest in filamentous fungi for pollution mitigation is corroborated by an overwhelming amount of research; however, no full-scale applications are currently known. Environmental pollution is a reality and production of ordinary sidestreams and micropollutant-rich wastewaters continuous. The establishment of filamentous fungal processes needs collaboration among governmental authorities, industries, and academics in order to tackle knowledge gaps within the area and propose a holistic approach.
\end{abstract}

Keywords Filamentous fungi $\cdot$ Pollution mitigation $\cdot$ Micropollutants $\cdot$ Paradigm shift $\cdot$ Sidestreams $\cdot$ Wastewater

\section{Introduction}

Anthropogenic activities have impaired the world's biogeochemical cycles. Earth's resources are funneled into industrial processes and intensified agricultural practices, to meet the demands of an increasing population with improving standard of living [1]. The biogeochemical disturbance is amplified by the absence of worldwide efficient treatment systems for the

This article is part of the Topical Collection on Water Pollution

Mohammad J. Taherzadeh

Mohammad.Taherzadeh@hb.se

1 Swedish Centre for Resource Recovery, University of Borås, 50190 Borås, Sweden

2 Gujarat Pollution Control Board, Gandhinagar, Gujarat 382010, India originated municipal, industrial, and agricultural sidestreams or wastewaters, rich in carbohydrates, protein, fat, minerals, etc. This can contribute to high loads of organic and inorganic matter in conventional wastewater treatment plants (WWTPs), informal discharges into the environment, soil and water eutrophication, landfilling, etc. Some strategies are applied by dairy, agro, paper and pulp, and biofuel industries, to extract further value from the sidestreams with concomitant reduced levels of chemical oxygen demand (COD) [2]. However, high energy consumption and low revenues are coupled to these initiatives and these sectors can benefit from superior economic and environmental valorization [3].

In line with increased industrialization and population, and improved standard of living, chemical industries (e.g., petrochemical, pharmaceutical, textile, tanning, pesticides, and fertilizers) and households generate wastewaters with such variability of compounds (e.g., dyes, hormones, hydrocarbons, 
heavy metals), which surpassed the cutting-edge technology of WWTPs [4]. These compounds are recalcitrant to biodegradation and can become volatilized, and toxic effects in all life forms have increasingly been reported, hence their classification into micropollutants, emerging pollutants, or contaminants of emerging concern $[5,6 \bullet]$.

Due to ecosystem integration, improperly treated wastewaters; leachates from landfills and runoffs from, e.g., agricultural practices; informal discharges and spills; and direct soil administration of industrial sidestreams lead to water, soil, and air pollution [7-10]. Environmental saturation is even jeopardizing the development of green processes and products. For instance, the soil administration of fertilizers originated from anaerobic digestion of wastes might need to be reduced due to eutrophication of soil and presence of micropollutants in the digestate [11]. Therefore, pollution mitigation strategies centered on, e.g., reducing the COD of industrial sidestreams, ensuring wastewater treatment before disposal, reducing landfilling, and ensuring landfill isolation, are no longer sufficient. Efficient systems need to be developed to decrease the COD of ordinary industrial sidestreams in the form of valuable products that can re-enter anthropogenic activities and reduce the loading into WWTPs, and to remove the wide range of micropollutants escaping from conventional WWTPs, landfills, chemical industries, and other anthropogenic activities, to avoid accumulation in the environment. Therefore, advanced strategies are needed to prevent further environmental pollution, and also for remediation of already polluted aquatic and terrestrial ecosystems.

Filamentous fungi are ubiquitous in nature, playing key roles in nutrient cycles and maintaining ecosystem balance [12]. Their metabolic diversity has been transferred into industrial processes, supplying a range of products [13], and into research initiatives towards valorization of industrial sidestreams $[14,15]$, and micropollutants removal from WWTPderived effluents $[16 \bullet \cdot]$, and from aquatic and terrestrial ecosystems [17]. Considering their ecological significance, and proven industrial application and research interest, filamentous fungi reunite suitable properties to provide a multidimensional contribution to pollution mitigation. These include their filamentous and macroscopic growth, array of enzymes, capacity of surfactant production and cell wall sorption, range of value-added products possible to be produced, and synergistic outputs when co-cultured with other groups of microorganisms. These characteristics provide overall advantage over unicellular microorganisms such as bacteria, yeasts, and algae, due to easier biomass recovery from the medium, lower substrate specificity, higher substrate bioavailability, and potential for wider range of processes. They also provide advantage over physicochemical processes for wastewater treatment since value-added products can be produced, potentially with comparatively lower energy and chemical consumption. Mimicking the dominant role of filamentous fungi in, e.g., natural nutrient cycles, can actually lead to a paradigm shift where organic and inorganic matter, with potential negative environmental impacts, are viewed as opportunities to attain a sustainable circular society.

The potential of filamentous fungi in pollution mitigation has been reviewed in a high number of high-quality scientific reviews; however, it has been done in a compartmentalized fashion. Researchers have been providing an overview of the achievements using filamentous fungi when grown in ordinary sidestreams (e.g., sidestreams from food industries rich in carbohydrates, proteins, minerals, etc.), or on the potential of filamentous fungi for removal of micropollutants present in wastewaters or WWTP-derived effluents. Considering the multidimensional role that filamentous fungi can play in pollution mitigation, knowledge integration among different application matrices is crucial in order to build new and costeffective processes, centered on a holistic approach. Such knowledge integration and holistic proposal are the overall aims of the present review.

\section{Filamentous Fungi}

\section{Distinctive Properties}

Filamentous fungi are ubiquitous in nature, with an important role in maintaining the ecosystems' status quo through decomposition of organic matter, nutrient recycling, and symbiotic interactions [12]. Filamentous fungi are phylogenetically diverse; however, members of three groups, namely ascomycetes, basidiomycetes, and zygomycetes, are mostly found in association with pollution mitigation research studies, or commercial exploitation [18], using high-quality medium recipes. Their dominant ecological role, extensive use in research, and commercial exploitation are related to the macroscopic filamentous growth, phylogenetic diversity, array of extracellular and intracellular enzymes, range of potential value-added products, production of surfactants, cell wall sorption, and synergistic possibilities in co-culture approaches.

In addition to filamentous fungi, bioconversion can be carried out with bacteria, yeasts, and algae. However, in view of the macroscopic filamentous structure which is easily recoverable from the medium, processes using filamentous fungi are economically less sensitive to the choice of cell mass recovery strategies. Recovery of the filamentous mass can be accomplished by simple sieving, while, e.g., energy-intensive centrifugation is needed if other microbial groups are used. For instance, recovery of microalgal biomass is one the biggest bottlenecks for feasibility, and the use of filamentous fungi to induce flocculation and easier recovery has been investigated [19]. Consequently, processes involving filamentous fungi benefit from easier extraction of value from biomass, and from the reduction of COD, medium viscosity [3], 
and production of sludge [20]. Furthermore, the filamentous structure increases the contact surface area to potential substrates [21] and provides the mechanical strength necessary for hyphal penetration, increasing overall access to nutrients. This provides the capability of filamentous fungi to penetrate soil and complex substrates such as lignocellulosic residues $[22 \cdot, 23]$, and access micropollutants present at very low concentrations, deposited on sediments, or in complexes with particulate matter [24]. The production of surfactants contributes further to the bioavailability of substrates present at low concentrations [25]; this is of especial importance for removal of micropollutants since their concentrations can range from the scale of nanograms per liter to milligrams per liter [16*0].

Hyphal extension and branching result from the assimilation of nutrients and co-production of needed extracellular and intracellular enzymes. Extracellular enzymes can include invertases, amylases, proteases, pectinases, cellulases, xylanases, lignin-modifying enzymes (oxidoreductases, namely laccases and peroxidases), keratinases, lipases, among others. The variety of extracellular enzymes provides growth versatility to filamentous fungi and their growth has been reported in an extensive range of industrial sidestreams containing sucrose, starch, protein, lignocellulose, keratin, and fat $[14,15,23,26]$. Ligninmodifying enzymes are actually behind the research boom on the use of filamentous fungi for removal of micropollutants. Due to their low substrate specificity, lignin-modifying enzymes have been investigated for the removal of the main groups of micropollutants present in effluents from WWTPs or in aquatic and terrestrial ecosystems [27, 28•]. Extracellular enzymes can lead to the conversion of complex substrates into single-unit compounds that can then enter the cell to follow intracellular metabolism, or to the detoxification of micropollutants that can enter (or not) into intracellular metabolic routes [29]. Clearly, filamentous fungi are also a source of a wide range of intracellular enzymes that may or may not work in tandem with extracellular enzymes. In addition to the catabolic reactions, responsible for using compounds as energy and carbon sources and common to all microorganisms, filamentous fungi produce intracellular enzymes of especial interest for conversion of micropollutants, namely cytochrome P450 monooxygenases, epoxide hydrolases, and various transferases [27]. Following intracellular conversion, micropollutants can either be stored within the cell or secreted to the surrounding medium [29], where they can be further degraded by other microorganisms [27], similarly to natural nutrient cycles. Yet, cell wall accounts for a great fraction of the fungal biomass and its importance for sorption of micropollutants such as heavy metals is well documented in the literature [30]. It is important to mention, however, that extracellular and intracellular enzymes, cell wall, and surfactants can work in tandem for the removal or detoxification of micropollutants, where the type of micropollutants and fungal strain dictates their contribution level $[16 \bullet, 31]$.
The momentum of filamentous fungi towards symbiotic associations in nature has also been brought to research approaches, where synergistic mechanisms were reported during co-culture of different strains of filamentous fungi or of these with bacteria, algae, and plants [32-34]. This is of especial relevance for removal of micropollutants in microbial heterogeneous wastewaters and ecosystems, and for process optimization (e.g., easier recovery of algal biomass as aforementioned).

\section{A Paradigm Shift for Pollution Perception?}

Industries and households release a wide range of compounds that can lead to environmental, social, economic, and health consequences in the absence of efficient treatment processes. The range of strains, enzymes, and products identified to date points out the potential of filamentous fungi to assimilate, detoxify, or degrade most of (if not all) these compounds, as well as to produce a wide range of products with anthropogenic applications. Therefore, sidestreams and wastewaters from industries, municipalities, and WWTPs, rich in organic and inorganic nutrients, can be directed into filamentous fungal processes for production of value-added products and easier clean water reclamation (Fig. 1). The role of filamentous fungi in nature has been transferred into industries for production of, e.g., organic acids, antibiotics, enzymes, and human fermented foods, using high-quality medium recipes [18]. Transferring further their capabilities into the use of lowvalue sidestreams and wastewaters as growth recipes could lead to a paradigm shift regarding the perception of environmental pollution related to anthropogenic activities. To this, the intensification of the development of efficient processes driving sidestreams and wastewaters away from the environment in parallel with in situ or ex situ bioremediation of polluted sites needs to become a reality.

Nonetheless, the composition of ordinary sidestreams and that of wastewaters are dissimilar leading to different challenges during the path towards feasible processes. Ordinary sidestreams are leftovers from removal of the main product targeted by the industry and are generally related to processing of renewable feedstocks. Therefore, these sidestreams are rich in carbohydrates, proteins, minerals, fat, etc. that can be converted to value-added products by filamentous fungi. Respiration leads to, e.g., the production of cell mass and a wide range of organic acids, while the fermentative pathway can lead to ethanol production. These sidestreams can contain more than $10 \%$ total solids, and through process development, high concentrations of value-added products can be achieved. The main bottlenecks for economic process development are thought to be related to finding the right combination of sidestream, filamentous fungus, and desired value-added product. For instance, if organic acids are envisaged, high conversion yields are necessary in order to cope with the recovery and 
Fig. 1 Overall scheme of the role filamentous fungi can play in pollution mitigation. Through conversion of industrial sidestreams and removal of micropollutants, value-added products and clean water can be obtained that can re-enter anthropogenic activities. Therefore, a sustainable circular society can be realized together with a paradigm shift on the perception of pollution mitigation

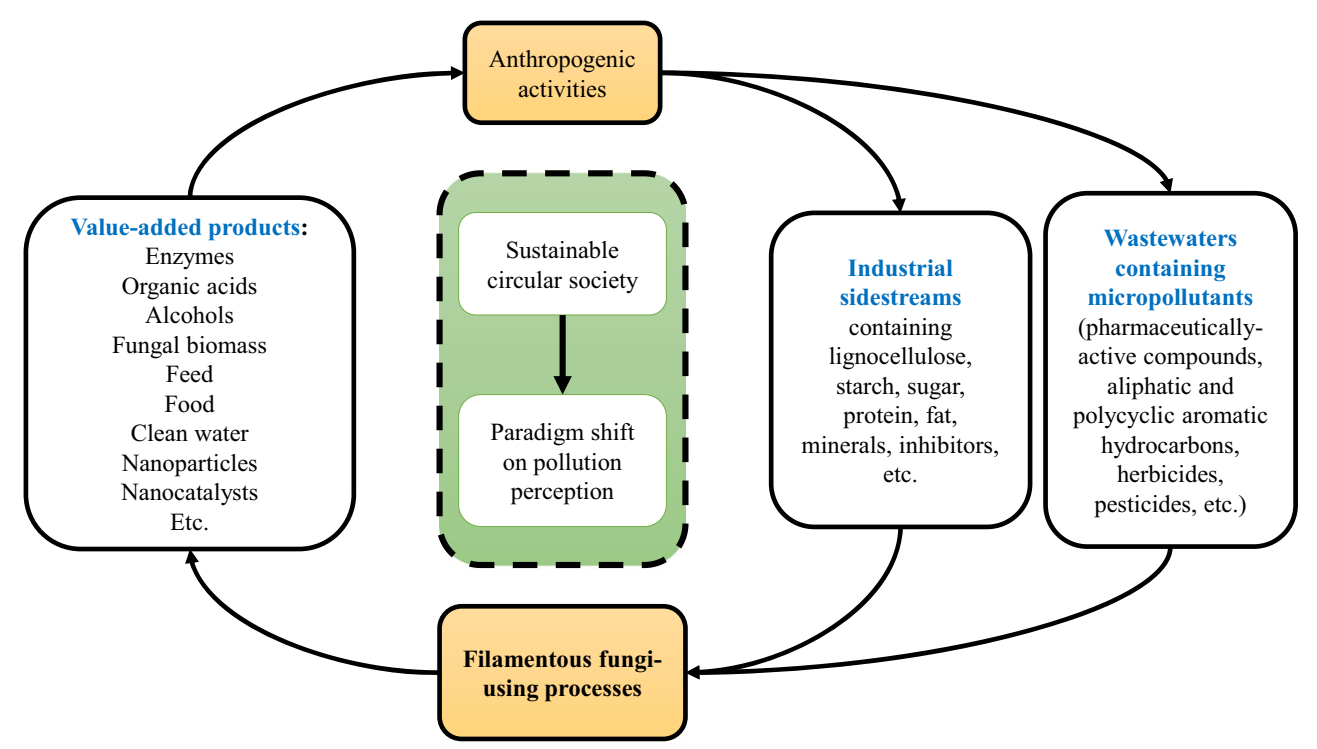

purification costs, while competing with baker's yeast capability to produce and tolerate ethanol is a challenging task. Naturally, other factors such as reactor design, aeration, mixing, and any other supplements such as $\mathrm{pH}$ adjustment chemicals or nutrients also play a role in the process economy.

Wastewaters have a completely different composition, where hormones, hydrocarbons, dyes, heavy metals, etc. can be found. Right at the beginning, wastewaters have several disadvantages in comparison with ordinary sidestreams, namely the lack of commonly use carbohydrates by filamentous fungi and nitrogen sources, and the compounds present are at very low concentrations. Altogether, energy and additional nutrients are spent to provide proper conditions for removal of micropollutants, while low concentrations of biomass and enzymes, the only products possible, are obtained. Therefore, at first glance alternatives are needed to find lowcost additional nutrients, high-value applications for the biomass, and processes that attain high-rate removal of micropollutants. These aspects are taken into consideration during the discussion that follows centered on a holistic approach. Efforts were made to propose as many strategies as possible for integration of valorization of ordinary sidestreams with removal of micropollutants from wastewaters by filamentous fungi.

\section{Filamentous Fungal Biomass-the Silver Lining for Feasible Processes?}

Filamentous fungal biomass is always generated independently of the intended valuable product to be produced (Fig. 1). The contribution of filamentous fungi to COD reduction of sidestreams is given by the assimilation of nutrients originating a macroscopic filamentous structure easily recovered from the medium. Therefore, it is the utmost importance to find end-uses for the produced biomass to avoid landfilling or incineration and contribution to gas emissions and leachates. Biorefining of fungal biomass is presently a need in view of the huge amounts of biomass produced at commercial-scale from established filamentous fungus-based processes [35]. For instance, the annual worldwide production of citric acid is estimated to give rise to 300,000 tons of fungal mycelium [36].

Increasing interest has been given to the nutritional quality of the filamentous fungal biomass in line with commercial exploitation for production of human food products. Several ascomycetes (e.g., Neurospora intermedia, Aspergillus oryzae, Monascus purpureus, and Fusarium venenatum) and zygomycetes (e.g., Rhizopus oryzae, Rhizopus oligosporus, Rhizopus microsporus var. oligosporus) filamentous fungi have been used for production of fermented foods, being recognized as GRAS (Generally Regarded As Safe) microorganisms [14, 15, 37] (Table 1). Their GRAS status is a suitable starting point for consideration of fungal biomass for feed applications. Fungal biomass grown in several different lowvalue sidestreams has been found to contain $40-60 \%$ protein, as well as profiles of amino acids and polyunsaturated fatty acids similar to those in fishmeal and soybean meal, presently the main protein sources for animal feed. Nonetheless, the entanglement of filaments with suspended matter might influence the final protein content of the sieved product [47]. This can have both positive and negative implications: recovered mixed fungal biomass with suspended solids from liquid sidestreams might lead to a product with lower protein content in comparison with that of pure fungal biomass, whereas recovered mixed fungal biomass with fibrous solid sidestreams can lead to the valorization of their protein content due to the replacement of, e.g., sugar in the fibers by protein-rich fungal biomass. In addition, the cell wall of fungal biomass, 
Table 1 Examples of Generally Regarded As Safe (GRAS) strains of filamentous fungi, protein contents of filamentous fungal biomass grown in different low-value substrates, and of main outputs obtained during the use of filamentous fungal biomass in animal feed

\begin{tabular}{|c|c|c|}
\hline \multicolumn{3}{|l|}{ A: Examples of GRAS strains of filamentous fungi } \\
\hline Strain & & Reference \\
\hline Aspergillus oryzae var. oryzae CBS 819.72 & & [38] \\
\hline Aureobasidium pullulans NRRL-Y-2311-1 & & [39] \\
\hline Fusarium venenatum ATCC 20334 & & {$[38]$} \\
\hline Fusarium venenatum NRRL 26139 & & [39] \\
\hline Monascus purpureus CBS 109.07 & & [38] \\
\hline Neurospora crassa NRRL 2710 & & [39] \\
\hline Neurospora intermedia CBS 131.92 & & {$[38]$} \\
\hline Paecilomyces variotti NRRL 1115 & & [39] \\
\hline Trichoderma reesei NRRL 3653 & & [39] \\
\hline Rhizopus delemar CBS 145940 (formerly “RM4”) & & {$[40]$} \\
\hline Rhizopus microscoporus var. oligosporus NRRL 2710 & & [39] \\
\hline Rhizopus microscoporus var. oligosporus ATCC 22959 & & {$[41]$} \\
\hline Rhizopus microsporus var. oligosporus CBS 112586 & & {$[42]$} \\
\hline Rhizopus oryzae CCUG 28958 & & {$[43]$} \\
\hline Rhizopus oligosporus NRRL 2710 & & {$[44]$} \\
\hline Mucor circinelloides f. lusitanicus CBS 277.49 & & {$[45]$} \\
\hline \multicolumn{3}{|l|}{ B: Protein content } \\
\hline Filamentous fungus and substrate & Protein content (\% dry weight) & Reference \\
\hline Various zygomycetes strains in semi-synthetic medium & $47-63$ & {$[40]$} \\
\hline Rhizopus microsporus var. oligosporus in vinasse & 49.7 & [41] \\
\hline Various ascomycetes and zygomycetes in stillage & $48-56$ & {$[38]$} \\
\hline Rhizopus oligosporus in stillage & 43 & {$[46]$} \\
\hline Various ascomycetes in expired dairy products & $30-40$ & {$[47]$} \\
\hline Neurospora intermedia in pretreated wheat straw & 51.6 & [48] \\
\hline \multicolumn{3}{|l|}{ C: Main outputs from animal feeding studies } \\
\hline Study condition & Main output & Reference \\
\hline $\begin{array}{l}\text { Rhizopus oryzae biomass, grown in spent sulfite liquor, } \\
\text { was included at } 30 \% \text { in the feed recipe for Arctic } \\
\text { charr and Eurosian perch }\end{array}$ & $\begin{array}{l}\text { Normal feed intake; no significant differences } \\
\text { in digestibility }\end{array}$ & [49] \\
\hline $\begin{array}{l}\text { Rhizopus oryzae biomass, grown in spent sulfite liquor, } \\
\text { was included at } 40 \% \text { in the feed recipe for Artic charr }\end{array}$ & $\begin{array}{l}\text { Minor mortality; improved muscle fatty acid profile; } \\
\text { higher level of monounsaturated fatty acids } \\
\text { and polyunsaturated fatty acids }\end{array}$ & {$[50]$} \\
\hline $\begin{array}{l}\text { Neurospora intermedia, grown in stillage, was included } \\
\text { at } 30 \% \text { in the feed recipe for broiler chickens }\end{array}$ & $\begin{array}{l}\text { No significant difference in feed intake and final body } \\
\text { weight; positive effects in immune responses and } \\
\text { in gut microbiota modification }\end{array}$ & {$[51]$} \\
\hline
\end{tabular}

according to the phylogenetic background, can contain chitosan, chitin, and $\beta$-glucans, with proven immunostimulant activities when used in feed recipes [52]. Promising results were obtained when fungal biomass originated from cultivation in different low-value substrates was included in animal feed recipes (Table 1). Furthermore, chitin and chitosan have been receiving increasing interest due to potential applications in pharma, cosmetics, bioplastics, biopolymers, biocomposites, and agricultural sectors [35]. More recent proposed applications for fungal biomass include its use for the production of supercapacitors [35] and construction bricks [53] and, if grown in heavy metal-rich media, it can become a potential source of environmentally friendly nanocatalysts and nanoparticles with application in, e.g., chemical industries, micropollutant removal approaches, and immobilizationbased enzymatic and whole-cell systems [54, 55•].

At first glance, the use of non-food-grade filamentous fungi might reduce the range of potential products from the biomass, and add focus to other products produced during the process (Fig. 1). However, both cell wall and protein fractions can be used for production of polymers and biocomposites [35], which can have a wide range of applications without entering the human chain. Moreover, as genomes of different filamentous fungi are continuously been made available, it 
might reveal absence of allergen-coding genes and therefore widen potential applications. One more potential application of residual fungal biomass, proposed by the authors, is its use as nutrients, similarly to the role played by yeast extract. This can be of especial interest for processes aiming at removal of micropollutants, where addition of nutrients is a limiting factor [12]. Naturally, the use of fungal biomass as nutrients can be extended to processes on valorization of sidestreams where nutrient supplementation is compulsory [56]. One example is spent sulfite liquor, a sidestream from paper and pulp mills, that needs supplementation for proper fungal growth [57].

Altogether, the establishment of a sub-biorefinery surrounding filamentous fungal biomass can greatly contribute to the feasibility of filamentous fungus-based processes, and this research line should be motivated in the future.

\section{Filamentous Fungal Cultivation Process}

Similar to their presence in both aquatic and terrestrial ecosystems, filamentous fungi have been cultivated in high water activity (submerged cultivation) and low water activity (solid-state cultivation - the term "solid-state fermentation" is commonly used, however, due to the aerobic character of the process, the term "cultivation" is used herein). Solidstate cultivation has been extensively studied for, e.g., production of enzymes (e.g., lignocellulose-degrading enzymes) [58-61] and pigments [62], for the valorization of substrate nutritional value (e.g., protein content) [63], and as a pretreatment step of lignocellulosic materials for further biorefining [23]. Nonetheless, solid-state cultivation is difficult to scale up and it still lacks the variability of reactor designs available for submerged cultivation. Solid-state cultivation is presently used for production of soybean-based fermented foods and mushrooms; however, it is characterized by small-scale production with simple equipment [64]. It is of the understanding of the authors that until a remarkable development is attained in the scale-up of solid-state cultivation, it is not a viable option for meeting the enzyme demands of various industrial sectors or for the removal of micropollutants in wastewaters produced at cumbersome volumes, despite being a strategy commonly used in research. Low water activity processes might however be a strong asset in the investigation of removal of micropollutants present in terrestrial ecosystems, or for the small-size valorization of solid wastes (e.g., apple pomace). Inversely, commercial-scale processes applying submerged cultivation of filamentous fungi are presently available supplying enzymes, antibiotics, organic acids, human food products, among others $[13,65]$. It should be noted, however, that these processes are normally characterized by the use of high-quality medium recipes [18].

The successful growth of filamentous fungi, as for other microbial groups, is attained by reuniting a range of proper conditions including medium composition, physicochemical cultivation conditions, and reactor design. Based on the growth characterization of filamentous fungi in diverse substrates, finding an adequate cultivation medium should not be considered a hurdle. High $\mathrm{C} / \mathrm{N}$ ratio cultivation medium, such as spent sulfite liquor from paper and pulp industry, can be balanced by, e.g., mixing with protein-rich substrates such as fish processing wastewater to reach $\mathrm{C} / \mathrm{N}$ ratios of 4 to 20 . Fish processing wastewater can also be a rich source of minerals [66], which are important for proper enzyme activity. Substrate mixing has widely been used in anaerobic digestion towards biogas production in order to attain adequate $\mathrm{C} / \mathrm{N}$ ratio and concentration of various compounds for proper bacterial activity [67-69]. However, it has not been widely explored for submerged cultivation of filamentous fungi. One example includes the work carried out by Nair et al. [70] during a research approach for integration of substrates used for production of first- and second-generation ethanol, namely sidestreams from ethanol production from starch and lignocellulosic materials, respectively. The proposed strategy would avoid the supplementation of the cultivation medium with costly nutrients that might also entail an environmental footprint. As aforementioned, the use of fungal biomass extract could provide another alternative to high-quality nutrients [71]. The medium recipe can, however, dictate the growth rate of filamentous fungi. If enzyme production is not envisaged, the growth rate in media containing proteins, fat, and disaccharides, such as sucrose or lactose, can be steered by the addition of extracellular enzymes, while the growth on lignocellulosic materials can be steered by carrying out energy- and chemical-intensive pretreatment followed by enzymatic hydrolysis. However, pretreatment-derived inhibitors might render nutrient supplementation compulsory [56]. Other growthinfluencing parameters naturally include $\mathrm{pH}$, temperature, and dissolved oxygen, which might have an impact on the costeffectiveness of the process. Filamentous fungi are characteristically acidophilic growing within $\mathrm{pH} 4-5.5$, at temperatures within $27-37^{\circ} \mathrm{C}$, and keeping dissolved oxygen saturation of $20 \%$ is advised under aerobic conditions. Naturally, variations can occur based on, e.g., fungal strain, fungal inoculum preparation, medium composition, and aerobic vs anaerobic character of the process.

Despite its importance for growth on complex substrates such as lignocellulosic materials, or superior access to micropollutants, fungal morphology can constitute a major bottleneck in submerged cultivation [72]. All cultivation parameters (medium composition and physicochemical parameters), including reactor design, influence fungal morphology that can take the form of mycelial suspensions with filaments evenly distributed throughout the medium, pellets, or clumps [72]. In turn, fungal morphology can dictate the type and concentration of products, and greatly influence medium rheological characteristics. Pellet morphology is generally 
preferred for biotechnological applications due to reduced medium viscosity, easy cell recycle, and wider choice of reactor designs [73••]. For instance, bubble columns and airlift bioreactors are generally preferred for cultivation of filamentous fungi, due to their simple inner structure free of spare parts, in comparison with stirred-tank bioreactors, where filaments can be attached to the spare parts and impair heat and mass transfer rates; pellet morphology can however facilitate the use of also stirred-tank bioreactors. Other bioreactor designs can be found coupled to the removal of micropollutants from wastewaters such as of the fluidized bed type, whereas hybrid bioreactors such membrane bioreactors have been, more recently, applied to both valorization of ordinary sidestreams and removal of micropollutants from wastewaters [73••]. Nonetheless, pellet texture (e.g., compactness vs fluffiness) and size influence mass and heat transfer rates and therefore cultivation performance. Furthermore, maintaining pellet texture and size is a hurdle in submerged cultivations [73••]. Altogether, if pellet morphology is identified as having a determining impact on process performance, it will delay process development since strain- and process setup-tailored morphology optimization is necessary. For instance, higher shearing rates will increase the probability of pellet formation; however, it might not hold true for all strains, different pellet textures will be produced among different strains, and other process parameters will co-influence morphology.

\section{Filamentous Fungi in the Valorization of "Ordinary" Sidestreams}

Agricultural and forestry practices and industrial processing of mostly plant-based renewable feedstocks give rise to various sidestreams of variable moisture and composition. These range from, e.g., straw left on the fields to, e.g., bagasse, peels, and various liquid streams at the industrial sites $[14,15]$. In general, substrates left on the fields are burnt, used for silage or directly for animal feed, while industrial streams have been used for energy recovery through, e.g., combustion; for production of animal feed; and for the production of biogas and fertilizer via anaerobic digestion [2]. In the absence of valorization strategies, the streams can join the municipal solid waste and ultimately landfilling, informally discarded into the environment, or directed to wastewater treatment. In view of their composition rich in, e.g., carbon, nitrogen, and mineral sources, all these streams are considered available for filamentous fungal bioconversion. The situation might not hold true for municipal waste where proper separation at source plays a role, and anaerobic digestion and compositing are well-established management processes [2].
Nowadays, the growth of filamentous fungi using a variety of sidestreams has been reported. This diversity can be found in available reviews $[3,14,15,18]$. In addition to their diversified enzyme network, filamentous fungi are capable of consuming both pentose and hexose sugars and demonstrate high inhibitor resistance, of particular interest for valorization of lignocellulosic materials [74-76].

The production of a similar range of products to that produced in large-scale filamentous fungal processes has been investigated using low-value streams. However, to the best of our knowledge, no industrial processes are presently available. This is hypothesized to be due to, e.g., an unbalance between substrate range investigated and in-depth substratetailored studies including fungal morphology control and process scale-up, and to the lack of academic-industrial integration that motivate general perceptions to be the benchmark while evaluating the cost-effectiveness of a given process. For instance, 1st-generation ethanol plants using mostly corn and wheat grains and sugarcane as feedstocks apply an energy-intensive process to evaporate and dry its ethanol distillation-derived leftovers for animal feed [74]. Through cultivation of Neurospora intermedia in wheat-derived thin stillage, the liquid fraction remaining after centrifugation of the leftovers known as stillage, extra $5 \mathrm{~g} / \mathrm{l}$ of ethanol was produced [77]. If considered as an isolated academic work, such ethanol production is not relevant since a low limit of $4-4.5 \%$ is normally considered for cost-effective recovery and purification. However, integration of this fungal cultivation into a facility possessing distillation columns for ethanol recovery and dryers for animal feed renders ethanol concentration limit obsolete and can lead to a yearly ethanol production improvement of $5.5 \%$, based on a facility producing $200,000 \mathrm{~m}^{3}$ of ethanol per year [77], energy savings due to reduced medium viscosity [78], and lower environmental impact [79]. A similar reasoning has been applied to cornderived stillage [46] and vinasse [37, 41,80], the counterpart from sugarcane-based ethanol production using the ascomycetes Neurospora intermedia and Aspergillus oryzae, and the zygomycetes Rhizopus oryzae and Rhizopus oligosporus, all GRAS filamentous fungi. The process development on cultivation of filamentous fungi in sidestreams originated after ethanol production and separation, using starchy materials, has been reported at bioreactor scales of up to $1600 \mathrm{~L}$. It is believed that such process-tailored approaches can open more filamentous fungus-based processes for valorization of industrial sidestreams. This is of especial importance for sugarcanebased sugar and ethanol industries, presently struggling with more restrict laws on direct land use and environmental discharges of vinasse [81]. However, there is a need for studies reporting fungal morphology control in low sidestreams, bioengineering studies identifying and proving crucial process scale-up parameters, and intensified techno-economic and life-cycle assessment studies. 


\section{Filamentous Fungi in the Removal of Micropollutants}

An increasing range of micropollutants is being detected in aquatic, terrestrial, and aerial (due to volatilization) ecosystems [24], which can adversely affect the health of all life forms [6•]. Micropollutants derive from improperly treated industries, hospitals, and households' wastewaters [6•], informal disposal, landfill and agricultural runoffs, spills $[17,82$, 83], incomplete combustion, etc. [84]. Micropollutants can include heavy metals, pharmaceutically active compounds, aliphatic and polycyclic aromatic hydrocarbons, pesticides, hormones, surfactants, textile dyes, and personal care products $[6 \cdot 17,85,86]$. In an attempt to remove these micropollutants, conventional WWTPs have been complemented with advanced physicochemical processes. These include advanced oxidation processes, membrane filtration, precipitation, flocculation, irradiation, adsorption, and chemical oxidation such as Fenton's oxidation, or a combination thereof, that is, hybrid systems $\left[6^{\bullet}\right]$. Nonetheless, these processes are costly, highly specific, inefficient, and lead to high production of sludge and formation of toxic side-products.

Biodegradation, using, e.g., filamentous fungi, has been considered a potential cost-effective and environmentally friendly alternative to physicochemical advanced processes $[6 \bullet]$. The discovery of the low substrate specificity of ligninmodifying enzymes from white-rot basidiomycetes fungi led to a research boom on the use of these filamentous fungi or their enzymes for removal of a wide range of micropollutants. A comparatively much lower focus has been given to zygomycetes and ascomycetes, as well as on the role of intracellular enzymes in fungal bioremediation. The scientific literature is rich in review works dedicated to lignin-modifying enzymes, that is, oxidoreductases $[6 \cdot 12$, $16 \bullet \bullet, 87 \bullet, 88]$, and to the overall review of the use of filamentous fungi or their enzymes for the bioremediation of polycyclic aromatic hydrocarbons $[17,87 \cdot, 89]$, pharmaceutically active compounds $[90 \bullet \bullet$, pesticides $[33,90 \bullet \cdot$, insecticides [91, 92], dyes [33, 86], hormones [93], and heavy metals $[21,30,85]$, together with a description of the conversion pathways. Furthermore, substantial knowledge has been acquired on fungal morphology and coupling whiterot fungi or their enzymes with various reactor designs $[16 \bullet \bullet, 73 \bullet \bullet]$ as well as on the synergistic effect of using coculture strategies $\left[22^{\bullet}\right]$, or combining white-rot fungi with nanomaterials [55 ${ }^{\circ}$. Despite the extensive amount of work carried out and knowledge available, no commercial application of white-rot fungus-based processes, or using other fungi or enzymes, for removal of micropollutants from WWTPs' wastewaters or effluents, and aquatic and terrestrial ecosystems, is presently known. A discussion on the main bottlenecks for application is provided in the following sections and future research avenues presented in Table 2.
Table 2 Proposed future research avenues on the use of filamentous fungi for pollution mitigation

A: Filamentous fungi in the valorization of "ordinary" sidestreams

- Processes should aim for products for which equipment is already in place: this will increase the rate of development based on integration approaches instead of single processes

- Decision on potential should be a result of intersectoral collaboration instead of commonly used bench marks (e.g., a low limit of 4\% ethanol might not be needed in all cases)

- Assimilation of nutrients with filamentous fungi does not normally reach 100\%: interdisciplinary approaches should be motivated in order to increase nutrient conversion yields

- Anaerobic digestion and wastewater treatment of sidestreams are commonly applied: research studies need to demonstrate the impact on these processes by including a pre-cultivation with filamentous fungi

- The extensive knowledge on fungal morphology needs to be brought to sidestreams containing solids: using only the liquid fraction might be possible if economically feasible

- Filamentous fungus-using processes based on intersectoral collaboration, techno-economic analysis, and life-cycle assessment need to become standard: this will widen the range of potential processes and provide information on the hotspots needed to be in focus in following research studies

B: Filamentous fungi in the removal of micropollutants

- The use of omics technologies need to be widespread regarding ecosystem and wastewater origin: if integrated with the development of analytical systems can reveal useful microorganisms or consortia, and increase the rate of description of transformation pathways for micropollutants and related potential toxicity

- Omics technologies should also be employed in in situ and ex situ bioremediation approaches of aquatic and terrestrial ecosystems: this will reveal the impact of bioaugmentation and biostimulation strategies on ecosystem community

- If removal of micropollutants from wastewater under nonsterile conditions becomes possible, omics technologies should also then be employed to reveal microbial community development, transformation pathways and related toxicity

- It is defended that reactor design development and scale-up should include an interdisciplinary approach combining knowledge on the growth of filamentous fungi and selectivity towards micropollutants with the development of membrane systems: this can reach complementing selectivity towards micropollutants, removal of bacteria, avoidance of mycelium and enzyme washout, and cultivation under nonsterile conditions a reality

- Valorization of "ordinary" sidestreams and micropollutant-rich wastewaters should be considered as integrated processes: knowledge sharing can tackle growth morphology bottlenecks, the need of fresh biomass and nutrients, and extend considerably the economic value of fungal biomass through biorefining

\section{Filamentous Fungal Strains and Consortia}

Removal of micropollutants by white-rot fungi and their enzymes has received dominant attention by the research community, translated in a high number of dedicated reviews. However, their transfer to real matrices, that is, WWTP effluents, and polluted aquatic and terrestrial 
ecosystems, is difficult and poorly investigated [16••, 88]. This has been assigned, among other aspects, to the existence of complex microbial networks that are directly or indirectly related to the bioremediation of micropollutants where white-rot fungi might not prevail [27]. Indeed, molecular techniques have revealed that filamentous fungi belonging to the Basidiomycota phylum play an inferior role in bioremediation in polluted environments in comparison with that of members of the phylum Ascomycota and subphylum Mucoromycotina. Furthermore, intracellular metabolism seems to play a major role in the bioremediation of, e.g., polycyclic aromatic hydrocarbons by these autochthonous fungi; however, the pathways are poorly understood [27]. Besides, some authors highlighted the value of laccase-producing marine filamentous fungi [28•] and of anaerobic filamentous fungi [94], also poorly investigated. Several studies in the literature have also shown synergistic behavior among different strains of filamentous fungi or of their combination with bacteria and plants for removal of micropollutants $[32,95]$. Yet, the expression of nonspecific lignin-modifying enzymes by basidiomycetes needs ligninolytic conditions and the presence of lignocellulosic materials, which might not prevail in polluted environments [27]. Therefore, the establishment of white-rot fungi processes for ex situ and in situ bioremediation of aquatic and terrestrial ecosystems needs characterization of the impact in the present community and interaction with autochthonous microorganisms. On the other hand, we hypothesize that, in the current situation, characterized by weak knowledge on microbial community and synergism, bioremediation of WWTP effluents with white-rot fungi may be only possible if cost-effective conditions are met allowing sterilization, or if the development of membrane bioreactors systems is mastered.

The development and increased focus on "omics" technologies is hypothesized as being the new silver lining within bioremediation $[27,94,96]$. "Omics" technologies will provide a more complete description of microbial networks related to the removal of micropollutants and of the impact of applying bioaugmentation and biostimulation approaches. Therefore, it can possibly clarify if white-rot fungi are the suitable approach for process development and help to identify tailored consortia for removal of micropollutants in several contaminated sites, both ecosystems and wastewaters. This might open the route for tailored in situ and ex situ bioremediation processes. Omics analyses should be carried out in as many marine and terrestrial ecosystems, including industrial wastewaters and WWTP effluents, as possible since microbial communities have evolved in order to tackle a toxic environment. This will contribute to a comprehensive characterization of the microbial community, unveil potential microorganisms or consortia for removal of micropollutants, and increase the application of bioremediation processes.

\section{Identification of Micropollutants and Transformation Products}

Chemical industries are based on the synthesis of an increasing range of products, hence the increasing range of micropollutants accumulating in the environment. This variability makes difficult a comprehensive knowledge on the type of micropollutants existing in nature and escaping from conventional WWTPs. The problem is exacerbated by the fact that awareness on the existence of micropollutants is relatively new and lacks efficient analytical methods [97]. Furthermore, the studies involving removal of micropollutants by filamentous fungi or their enzymes give rise to a variability of transformation pathways and a comprehensive knowledge on the transformation products is not presently available [27]. This is of utmost importance since some transformation products can actually be of higher toxicity than their parental compounds [98]. Accumulation of micropollutants in nature is a continuous process if efficient prevention methods are not put in place and a global efficiency is not envisaged in the near future. The development of efficient analytical techniques should be an integrated process among governmental organizations, micropollutant-emitting industries, academia, and WWTPs in order to obtain a comprehensive profile of micropollutants reaching WWTPs as well as of those already present in nature. Naturally, this knowledge will also help to identify microbial processes, based on single strain or consortia, as fully environmentally friendly. It is also defended that an integrated knowledge of the profile of micropollutants in several matrices with the knowledge from omics techniques can reveal relationships among micropollutants and adaptation of microbial communities, together with deep knowledge on transformation pathways.

\section{Medium Supplementation}

The expression of lignin-modifying enzymes is not characteristically constitutive, but rather co-metabolic [16・•]. Filamentous fungi able to use micropollutants as single carbon and nitrogen sources have not been widely reported [94]. Hence, the medium has normally to be supplemented with carbon and nitrogen sources to induce bioremediation [99]. This increases the cost of processes and production of sludge for application at WWTPs, and becomes process transfer to aquatic and terrestrial ecosystems rather difficult. The costs of the process can possibly be reduced if fungal biomass extract is used as nitrogen source. Such strategy has previously been reported, where zygomycetes fungal isolate replaced yeast extract in the production of ethanol and chitosan from glucose [71]. This could provide a valorization route for the fungal biomass produced by established commercial facilities or future processes leading to the valorization of "ordinary" sidestreams. Filamentous fungal biomass contains polysaccharides such as 
chitosan, chitin, and $\beta$-glucans; however, it remains to be revealed if such carbon sources can aid bioremediation. Alternative carbon sources other than refined glucose can potentially be provided by industrial sidestreams such as spent sulfite liquor, rich in monomeric sugars [57]. The potential of these proposed research avenues will depend on the impact on sludge production and wastewater treatment as well as on the possibility of establishing networks of ordinary sidestreams producers and wastewater treatment units, where distance will also play a role. There is also a need of classification of sidestreams into those aimed for bioremediation, focused on removal of micropollutants, and those aimed for valorization into products, for integration into anthropogenic activities. For instance, paper and pulp and olive oil industries generate sidestreams that have been considered in both perspectives.

\section{Growth Morphology}

Pellet morphology is normally preferred for biotechnological applications. Inducing pellet morphology during cultivation with filamentous fungi has been accomplished in several works [73••], and comprehensive reviews are available in the literature [73••, $100,101]$. The limitations are related to the texture (fluffiness vs compactness), size, and maintenance of suitable pellet morphology during cultivation. Fungal morphology is a very complex research area, where in principle cultivation setups found suitable might not be extrapolated into other systems employing different strains and cultivation recipes. Therefore, it all leads to the need of tailored process development. However, the fact that submerged cultivation of filamentous fungi is presently employed at the industrial scale [18], studies reporting morphology control [102] are available, and morphological engineering techniques [103] are gathering increasing interest, points out a promising future within sidestream valorization or wastewater remediation. It is defended, however, that knowledge integration is needed among both dimensions towards pollution mitigation to trigger faster process development. There is a substantial amount of knowledge acquired during submerged cultivation of filamentous fungi towards production of value-added products from high-quality medium recipes or sidestreams that can be brought into research on bioremediation of micropollutant-rich wastewaters and vice-versa.

\section{Whole-Cell Biocatalysts vs Enzymes}

Media containing high levels of micropollutants can become inhibitory to filamentous fungi and medium dilution is not attractive from a cost-efficiency point of view, or impractical in in situ bioremediation. Accordingly, isolated enzymes from white-rot fungi in either pure or crude form have extensively been used for removal of micropollutants [104]. The main drawbacks include the absence of cost-effective processes for production of these enzymes, in the context of application in bioremediation processes, and concerns on application in aquatic and terrestrial ecosystems [16••]. Moreover, since removal of micropollutants can be a result of integrated contribution of cell wall adsorption, and extracellular and intracellular enzymes, the use of whole-cell biocatalysts might provide a broader range of micropollutants that can be removed/detoxified [104].

Immobilization has been investigated in order to enhance recycling and stability of enzymes and cell washup [12, 30]. In a broader perspective, there are no commercial processes employing immobilization strategies, and therefore, their use in the removal of micropollutants is doubtful. However, costeffectiveness of the process could gain from the use of chitosan, originated from fungal biomass from established commercial processes or routes leading to valorization of "ordinary" sidestreams, or from nanoparticles produced from fungal biomass grown in heavy metal-rich media; both have been used in immobilization [12]. Furthermore, pellet morphology is regarded as natural immobilization and rigid morphology control and washup avoidance could offset the interest on other immobilization strategies.

\section{Reactor Design and Scale-up}

Several reactor designs have been developed in parallel with fungal morphology studies and some interesting alternatives presently exist [73••]. Studies using filamentous fungi for the removal of micropollutants have been reported at reactor scale of up to $10 \mathrm{~L}$, where the use of fluidized-bed bioreactors dominates [16••, 73••]. Other reactor designs used for removal of micropollutants include bubble column, airlift, and stirredtank bioreactors, and hybrid reactors such as membrane bioreactors $[73 \bullet \bullet$. It is defended in this review, that efficient control of fungal morphology together with membranes, that is, membrane bioreactors could open up further possibilities for process development. Membranes would function as a complement to all characteristics of filamentous fungi needed for efficient removal of micropollutants, since they are selective barriers [105]. Indeed, the only example of application of filamentous fungi for removal of micropollutants at full-scale WWTP included a membrane bioreactor with a total capacity of $1000 \mathrm{~L}$ [106]. Therefore, knowledge integration of fungal morphology, reactor design, and comprehensive analysis of micropollutants and transformation products, can lead to the development of tailored and robust systems. Nonetheless, governmental initiatives need to motivate higher level integration between producers of micropollutants, WWTPs, and academic research groups to intensify the scale-up of these systems. Mastering the use of membrane bioreactors can even tackle the need of sterilization, and avoid cell and enzyme washout. Although tailored systems might be needed, it is hypothesized that coupling biomass biorefining with highlyselective membrane bioreactors can become the silver lining of cost-effective micropollutant removal processes. 


\section{Conclusions}

This work has exposed the potential multidimensional application of filamentous fungi in pollution mitigation. Presently, there is extensive knowledge on potential substrate range for bioconversion by filamentous fungi, reactor design, morphology steering, and symbiotic relationships with other organisms. Nonetheless, there is a panoply of in-depth studies and analyses that are proposed for future research in this review. These can be specific to each of the two perspectives addressed in this review, namely valorization of "ordinary" sidestreams and micropollutant removal, or aiming at their integration. Overall, the increased interest and knowledge gathered from studies applying omics techniques should be motivated and coupled to strategies applying co-cultures or associating microorganisms to nanotechnology for removal of micropollutants; intersectoral collaboration needs to become routine in order to increase the range of potential strategies for valorization of sidestreams and provide a comprehensive view of the flows of micropollutants in various matrices; and fungal biomass biorefining into high-value applications should be another focus of future research works together with knowledge integration among strategies devoted to valorization of ordinary sidestreams and removal of micropollutants in wastewater with especial emphasis on tackling the need of nutrients in the latter. Environmental pollution is continuous, if not mitigate, and ecosystems will remain polluted, if not remediated. Integration of governmental organizations, industrials, and academic research groups can reunite the tools to translate the immense knowledge on filamentous fungi into processes for pollution mitigation and even to a paradigm shift due to the establishment of a sustainable circular society.

Funding Information Open access funding provided by University of Boras.

\section{Compliance with Ethical Standards}

Conflict of Interest The authors do not have any conflicts of interest.

Human and Animal Rights and Informed Consent This article does not contain any studies with human or animal subjects performed by any of the authors.

Open Access This article is licensed under a Creative Commons Attribution 4.0 International License, which permits use, sharing, adaptation, distribution and reproduction in any medium or format, as long as you give appropriate credit to the original author(s) and the source, provide a link to the Creative Commons licence, and indicate if changes were made. The images or other third party material in this article are included in the article's Creative Commons licence, unless indicated otherwise in a credit line to the material. If material is not included in the article's Creative Commons licence and your intended use is not permitted by statutory regulation or exceeds the permitted use, you will need to obtain permission directly from the copyright holder. To view a copy of this licence, visit http://creativecommons.org/licenses/by/4.0/.

\section{References}

Papers of particular interest, published recently, have been highlighted as:

- Of importance

•. Of major importance

1. Taherzadeh MJ. Bioengineering to tackle environmental challenges, climate changes and resource recovery. Bioengineered. 2019;10:698-9. https://doi.org/10.1080/21655979.2019. 1705065 .

2. Ferreira JA, Agnihotri S, Taherzadeh MJ. Waste biorefinery. In: Taherzadeh MJ, Bolton K, Wong J, Pandey A, editors. Sustainable resource recovery and zero waste approaches. Missouri: Elsevier; 2019. p. 35-52.

3. Ferreira JA, Brancoli P, Agnihotri S, Bolton K, Taherzadeh MJ. A review of integration strategies of lignocelluloses and other wastes in 1 st generation bioethanol processes. Process Biochem. 2018;75:173-86. https://doi.org/10.1016/j.procbio.2018.09.006.

4. Sudhakaran S, Maeng SK, Amy G. Hybridization of natural systems with advanced treatment processes for organic micropollutant removals: new concepts in multi-barrier treatment. Chemosphere. 2013;92:731-7. https://doi.org/10.1016/j. chemosphere.2013.04.021.

5. Teodosiu C, Gilca A-F, Barjoveanu G, Fiore S. Emerging pollutants removal through advanced drinking water treatment: a review on processes and environmental performances assessment. $\mathrm{J}$ Clean Prod. 2018;197:1210-21. https://doi.org/10.1016/j.jclepro. 2018.06.247.

6. Morsi R, Bilal M, Iqbal HMN, Ashraf SS. Laccases and peroxidases: The smart, greener and futuristic biocatalytic tools to mitigate recalcitrant emerging pollutants. Sci Total Environ. 2020;714:136572. https://doi.org/10.1016/j.scitotenv.2020. 136572 This review provides information on the role of oxidoreductases from different origins in bioremediation, together with transformation pathways.

7. Barbosa MO, Moreira NFF, Ribeiro AR, Pereira MFR, Silva AMT. Occurrence and removal of organic micropollutants: an overview of the watch list of EU Decision 2015/495. Water Res. 2016;94:257-79. https://doi.org/10.1016/j.watres.2016.02.047.

8. Song W, Huang M, Rumbeiha W, Li H. Determination of amprolium, carbadox, monensin, and tylosin in surface water by liquid chromatography/tandem mass spectrometry. Rapid Commun Mass Spectrom. 2007;21:1944-50. https://doi.org/10. 1002/rcm.3042.

9. Matthiessen P, Arnold D, Johnson AC, Pepper TJ, Pottinger TG, Pulman KGT. Contamination of headwater streams in the United Kingdom by oestrogenic hormones from livestock farms. Sci Total Environ. 2006;367:616-30. https://doi.org/10.1016/j. scitotenv.2006.02.007.

10. Luo Y, Guo W, Ngo HH, Nghiem LD, Hai FI, Zhang J, et al. A review on the occurrence of micropollutants in the aquatic environment and their fate and removal during wastewater treatment. Sci Total Environ. 2014;473-474:619-41. https://doi.org/10. 1016/j.scitotenv.2013.12.065.

11. Wainaina S, Lukitawesa L, Awasthi MK, Taherzadeh MJ. Bioengineering of anaerobic digestion for volatile fatty acids, hydrogen or methane production: a critical review. Bioengineered. 2019;10:437-58. https://doi.org/10.1080/21655979.2019. 1673937.

12. Kües U. Fungal enzymes for environmental management. Curr Opin Biotechnol. 2015;33:268-78. https://doi.org/10.1016/j. copbio.2015.03.006. 
13. Gibbs PA, Seviour RJ, Schmid F. Growth of filamentous fungi in submerged culture: problems and possible solutions. Crit Rev Biotechnol. 2000;20:17-48. https://doi.org/10.1080/ 07388550091144177.

14. Ferreira JA, Lennartsson PR, Edebo L, Taherzadeh MJ. Zygomycetes-based biorefinery: present status and future prospects. Bioresour Technol. 2013;135:523-32. https://doi.org/10. 1016/j.biortech.2012.09.064.

15. Ferreira JA, Mahboubi A, Lennartsson PR, Taherzadeh MJ. Waste biorefineries using filamentous ascomycetes fungi: present status and future prospects. Bioresour Technol. 2016;215:334-45. https://doi.org/10.1016/j.biortech.2016.03.018.

16.• Naghdi M, Taheran M, Brar SK, Kermanshahi-pour A, Verma M, Surampalli RY. Removal of pharmaceutical compounds in water and wastewater using fungal oxidoreductase enzymes. Environ Pollut. 2018;234:190-213. https://doi.org/10.1016/j.envpol.2017. 11.060 This review provides information on the use of oxireductases, in both crude and purified form, in bioremediation, including transformation pathways and reactor scale studies.

17. Daccò C, Girometta C, Asemoloye MD, Carpani G, Picco AM, Tosi S. Key fungal degradation patterns, enzymes and their applications for the removal of aliphatic hydrocarbons in polluted soils: a review. Int Biodeterior Biodegrad. 2020;147:104866. https://doi. org/10.1016/j.ibiod.2019.104866.

18. Troiano D, Orsat V, Dumont MJ. Status of filamentous fungi in integrated biorefineries. Renew Sust Energ Rev. 2020;117: 109472. https://doi.org/10.1016/j.rser.2019.109472.

19. Muradov N, Taha M, Miranda AF, Wrede D, Kadali K, Gujar A, et al. Fungal-assisted algal flocculation: application in wastewater treatment and biofuel production. Biotechnol Biofuels. 2015;8:24 . https://doi.org/10.1186/s13068-015-0210-6.

20. Vasiliadou IA, Sánchez-Vázquez R, Molina R, Martínez F, Melero JA, Bautista LF, et al. Biological removal of pharmaceutical compounds using white-rot fungi with concomitant FAME production of the residual biomass. J Environ Manag. 2016;180: 228-37. https://doi.org/10.1016/j.jenvman.2016.05.035.

21. Fernández PM, Viñarta SC, Bernal AR, Cruz EL, Figueroa LIC. Bioremediation strategies for chromium removal: current research, scale-up approach and future perspectives. Chemosphere. 2018;208:139-48. https://doi.org/10.1016/j.chemosphere.2018. 05.166.

22. Ijoma GN, Tekere M. Potential microbial applications of cocultures involving ligninolytic fungi in the bioremediation of recalcitrant xenobiotic compounds. Int J Environ Sci Technol. 2017;14:1787-806. https://doi.org/10.1007/s13762-017-1269-3 This review provides information on the use of co-cultures in bioremediation.

23. Wan C, Li Y. Fungal pretreatment of lignocellulosic biomass. Biotechnol Adv. 2012;30:1447-57. https://doi.org/10.1016/j. biotechadv.2012.03.003.

24. Ossai IC, Ahmed A, Hassan A, Hamid FS. Remediation of soil and water contaminated with petroleum hydrocarbon: a review. Environ Technol Innov. 2020;17:100526. https://doi.org/10.1016/ j.eti.2019.100526.

25. Souza EC, Vessoni-Penna TC, de Souza Oliveira RP. Biosurfactant-enhanced hydrocarbon bioremediation: an overview. Int Biodeterior Biodegrad. 2014;89:88-94. https://doi.org/ 10.1016/j.ibiod.2014.01.007.

26. Sharma R, Devi S. Versatility and commercial status of microbial keratinases: a review. Rev Environ Sci Biotechnol. 2018;17:1945. https://doi.org/10.1007/s11157-017-9454-x.

27. Aranda E. Promising approaches towards biotransformation of polycyclic aromatic hydrocarbons with Ascomycota fungi. Curr Opin Biotechnol. 2016;38:1-8. https://doi.org/10.1016/j.copbio. 2015.12.002.
28. Theerachat M, Guieysse D, Morel S, Remaud-Siméon M, Chulalaksananukul W. Laccases from marine organisms and their applications in the biodegradation of toxic and environmental pollutants: a review. Appl Biochem Biotechnol. 2019;187:583611. https://doi.org/10.1007/s12010-018-2829-9 This review provides information on the potential of using marine organisms in bioremediation as an alternative to white-rot fungi.

29. Olicón-Hernández DR, González-López J, Aranda E. Overview on the biochemical potential of filamentous fungi to degrade pharmaceutical compounds. Front Microbiol. 2017;8. https://doi.org/ 10.3389/fmicb.2017.01792.

30. Velkova Z, Kirova G, Stoytcheva M, Kostadinova S, Todorova K, Gochev V. Immobilized microbial biosorbents for heavy metals removal. Eng Life Sci. 2018;18:871-81. https://doi.org/10.1002/ elsc. 201800017.

31. Chandra R, Chowdhary P. Properties of bacterial laccases and their application in bioremediation of industrial wastes. Environ Sci. 2015;17:326-42. https://doi.org/10.1039/C4EM00627E.

32. Fester T. Arbuscular mycorrhizal fungi in a wetland constructed for benzene-, methyl tert-butyl ether- and ammonia-contaminated groundwater bioremediation. Microb Biotechnol. 2013;6:80-4. https://doi.org/10.1111/j.1751-7915.2012.00357.x.

33. de Lima DP, dos Santos EA, Marques MR, Giannesi GC, Beatriz A, Yonekawa MKA, et al. Fungal bioremediation of pollutant aromatic amines. Curr Opin Green Sustain Chemi. 2018;11:34 44. https://doi.org/10.1016/j.cogsc.2018.03.012.

34. Xie S, Sun S, Dai SY, S. Yuan J. Efficient coagulation of microalgae in cultures with filamentous fungi. Algal Res. 2013;2:28-33. https://doi.org/10.1016/j.algal.2012.11.004.

35. Isaza-Pérez F, Ramírez-Carmona M, Rendón-Castrillón L, Ocampo-López C. Potential of residual fungal biomass: a review. Environ Sci Pollut Res. 2020;27:13019-31. https://doi.org/10. 1007/s11356-020-08193-6.

36. Banner T, Fosmer A, Jessen H, Marasco E, Rush B, Veldhouse J, et al. Microbial bioprocesses for industrial-scale chemical production. Biocatal Green Chem Chem Process Develop. 2011;429: 467. https://doi.org/10.1002/9781118028308.

37. Nitayavardhana $S$, Khanal SK. Innovative biorefinery concept for sugar-based ethanol industries: production of protein-rich fungal biomass on vinasse as an aquaculture feed ingredient. Bioresour Technol. 2010;101:9078-85. https://doi.org/10.1016/j.biortech. 2010.07.048.

38. Ferreira JA, Lennartsson PR, Taherzadeh MJ. Production of ethanol and biomass from thin stillage using food-grade Zygomycetes and Ascomycetes filamentous fungi. Energies. 2014;7:3872-85. https://doi.org/10.3390/en7063872.

39. Zahler J, Karki B, Isaac I, Gibbons W. Assessing various types of fungal strains to convert soybean processing industry wastewater into protein-rich animal feed. J Microbial Biochem Technol. 2018;10:20-4. https://doi.org/10.4172/1948-5948.1000390.

40. Wikandari R, Millati R, Lennartsson P, Harmayani E, Taherzadeh $\mathrm{M}$. Isolation and characterization of Zygomycetes fungi from Tempe for ethanol production and biomass applications. Appl Biochem Biotechnol. 2012;167:1501-12. https://doi.org/10. 1007/s12010-012-9587-x.

41. Nitayavardhana S, Issarapayup K, Pavasant P, Khanal SK. Production of protein-rich fungal biomass in an airlift bioreactor using vinasse as substrate. Bioresour Technol. 2013;133:301-6. https://doi.org/10.1016/j.biortech.2013.01.073.

42. Wainaina S, Kisworini AD, Fanani M, Wikandari R, Millati R, Niklasson C, et al. Utilization of food waste-derived volatile fatty acids for production of edible Rhizopus oligosporus fungal biomass. Bioresour Technol. 2020;310:123444. https://doi.org/10. 1016/j.biortech.2020.123444. 
43. Gurram R, Souza Filho PF, Taherzadeh MJ, Zamani A. A solventfree approach for production of films from pectin and fungal biomass. J Polym Environ. 2018;26:4282-92. https://doi.org/10. 1007/s10924-018-1300-x.

44. Kuligowski M, Pawłowska K, Jasińska-Kuligowska I, Nowak J. Isoflavone composition, polyphenols content and antioxidative activity of soybean seeds during tempeh fermentation. CyTA - J Food. 2017;15:27-33. https://doi.org/10.1080/19476337.2016. 1197316.

45. Mitra D, Rasmussen ML, Chand P, Chintareddy VR, Yao L, Grewell D, et al. Value-added oil and animal feed production from corn-ethanol stillage using the oleaginous fungus Mucor circinelloides. Bioresour Technol. 2012;107:368-75. https://doi. org/10.1016/j.biortech.2011.12.031.

46. Rasmussen ML, Khanal SK, Pometto AL, van Leeuwen J. Water reclamation and value-added animal feed from corn-ethanol stillage by fungal processing. Bioresour Technol. 2014;151:284 90. https://doi.org/10.1016/j.biortech.2013.10.080.

47. Mahboubi A, Ferreira JA, Taherzadeh MJ, Lennartsson PR. Value-added products from dairy waste using edible fungi. Waste Manag. 2017;59:518-25. https://doi.org/10.1016/j. wasman.2016.11.017.

48. Nair RB, Kabir MM, Lennartsson PR, Taherzadeh MJ, Horváth IS. Integrated process for ethanol, biogas, and edible filamentous fungi-based animal feed production from dilute phosphoric acidpretreated wheat straw. Appl Biochem Biotechnol. 2018;184:48 62. https://doi.org/10.1007/s12010-017-2525-1.

49. Langeland M, Vidakovic A, Vielma J, Lindberg JE, Kiessling A, Lundh T. Digestibility of microbial and mussel meal for Arctic charr (Salvelinus alpinus) and Eurasian perch (Perca fluviatilis). Aquac Nutr. 2014;22:485-95. https://doi.org/10.1111/anu.12268.

50. Wagner L, Gomez Requeni P, Moazzami A, Lundh T, Vidakovic A, Langeland M, et al. 1H NMR-based metabolomics and lipid analyses revealed the effect of dietary replacement of microbial extracts or mussel meal with fish meal to arctic charr (Salvelinus alpinus). Fishes. 2019;4:46. https://doi.org/10.3390/ fishes4030046.

51. Rezaei M, Wall H, Tarshan M, Ivarsson E. Evaluation of broiler chickens' digestibility of Neurospora intermedia biomass. Poult Sci. 2019;98:5017-22. https://doi.org/10.3382/ps/pez174.

52. Karimi S, Mahboobi Soofiani N, Mahboubi A, Taherzadeh MJ. Use of organic wastes and industrial by-products to produce filamentous fungi with potential as aqua-feed ingredients. Sustainability. 2018;10:3296. https://doi.org/10.3390/ su10093296.

53. Ramrakhiani L, Ghosh S, Majumdar S. Surface modification of naturally available biomass for enhancement of heavy metal removal efficiency, upscaling prospects, and management aspects of spent biosorbents: a review. Appl Biochem Biotechnol. 2016;180: 41-78. https://doi.org/10.1007/S12010-016-2083-Y.

54. Kratošová G, Holišová V, Konvičková Z, Ingle AP, Gaikwad S, Škrlová K, et al. From biotechnology principles to functional and low-cost metallic bionanocatalysts. Biotechnol Adv. 2019;37: 154-76. https://doi.org/10.1016/j.biotechadv.2018.11.012.

55. Huang D, Guo X, Peng Z, Zeng G, Xu P, Gong X, et al. White rot fungi and advanced combined biotechnology with nanomaterials: promising tools for endocrine-disrupting compounds biotransformation. Crit Rev Biotechnol. 2018;38:671-89. https://doi.org/10. $1080 / 07388551.2017 .1386613$ In addition to transformation pathways for various micropollutants using white-rot fungi, this review provides information on the potential of combining white-rot fungi with nanomaterials in bioremediation.

56. Nair RB, Lundin M, Lennartsson PR, Taherzadeh MJ. Optimizing dilute phosphoric acid pretreatment of wheat straw in the laboratory and in a demonstration plant for ethanol and edible fungal biomass production using Neurospora intermedia. J Chem
Technol Biotechnol. 2017;92:1256-65. https://doi.org/10.1002/ jetb.5119.

57. Ferreira JA, Lennartsson PR, Niklasson C, Lundin M, Edebo L, Taherzadeh MJ. Spent sulphite liquor for cultivation of an edible Rhizopus sp. Bioresources. 2012;7:173-88.

58. Brijwani K, Oberoi HS, Vadlani PV. Production of a cellulolytic enzyme system in mixed-culture solid-state fermentation of soybean hulls supplemented with wheat bran. Process Biochem. 2010;45:120-8. https://doi.org/10.1016/j.procbio.2009.08.015.

59. Pandey A, Selvakumar P, Soccol CR, Nigam P. Solid state fermentation for the production of industrial enzymes. Curr Sci. 1999;77:149-62.

60. Rodríguez Couto S, Sanromán MA. Application of solid-state fermentation to ligninolytic enzyme production. Biochem Eng J. 2005;22:211-9. https://doi.org/10.1016/j.bej.2004.09.013.

61. Graminha EBN, Gonçalves AZL, Pirota RDPB, Balsalobre MAA, Da Silva R, Gomes E. Enzyme production by solid-state fermentation: application to animal nutrition. Anim Feed Sci Technol. 2008;144:1-22. https://doi.org/10.1016/j.anifeedsci.2007.09.029.

62. Gmoser R, Sintca C, Taherzadeh MJ, Lennartsson PR. Combining submerged and solid state fermentation to convert waste bread into protein and pigment using the edible filamentous fungus N. intermedia. Waste Manag. 2019;97:63-70. https://doi.org/10. 1016/j.wasman.2019.07.039.

63. Ibarruri J, Cebrián M, Hernández I. Solid state fermentation of brewer's spent grain using Rhizopus sp. to enhance nutritional value. Waste Biomass Valori. 2019;10:3687-700. https://doi. org/10.1007/s12649-019-00654-5.

64. Chen J, Zhu Y. Solid state fermentation for foods and beverages. Boca Raton: CRC Press; 2013.

65. Wiebe M. Myco-protein from Fusarium venenatum: a wellestablished product for human consumption. Appl Microbiol Biotechnol. 2002;58:421-7. https://doi.org/10.1007/s00253-0020931-x.

66. Regueiro L, Carballa M, Álvarez JA, Lema JM. Enhanced methane production from pig manure anaerobic digestion using fish and biodiesel wastes as co-substrates. Bioresour Technol. 2012;123:507-13. https://doi.org/10.1016/j.biortech.2012.07. 109.

67. Hagos K, Zong J, Li D, Liu C, Lu X. Anaerobic co-digestion process for biogas production: progress, challenges and perspectives. Renew Sust Energ Rev. 2017;76:1485-96. https://doi.org/ 10.1016/j.rser.2016.11.184.

68. Astals S, Musenze RS, Bai X, Tannock S, Tait S, Pratt S, et al. Anaerobic co-digestion of pig manure and algae: impact of intracellular algal products recovery on co-digestion performance. Bioresour Technol. 2015;181:97-104. https://doi.org/10.1016/j. biortech.2015.01.039.

69. Nghiem LD, Koch K, Bolzonella D, Drewes JE. Full scale codigestion of wastewater sludge and food waste: bottlenecks and possibilities. Renew Sust Energ Rev. 2017;72:354-62. https://doi. org/10.1016/j.rser.2017.01.062.

70. Nair RB, Osadolor OA, Ravula VK, Lennartsson PR, Taherzadeh MJ. Lignocellulose integration to $1 \mathrm{G}$-ethanol process using filamentous fungi: fermentation prospects of edible strain of Neurospora intermedia. BMC Biotechnol. 2018;18:49. https:// doi.org/10.1186/s12896-018-0444-Z.

71. Asachi R, Karimi K, Taherzadeh MJ. Fungal autolysate as a nutrient supplement for ethanol and chitosan production by Mucor indicus. Biotechnol Lett. 2011;33:2405-9. https://doi.org/10. 1007/s10529-011-0725-2.

72. Papagianni M. Fungal morphology and metabolite production in submerged mycelial processes. Biotechnol Adv. 2004;22:189 259. https://doi.org/10.1016/j.biotechadv.2003.09.005.

73.• Espinosa-Ortiz EJ, Rene ER, Pakshirajan K, van Hullebusch ED, Lens PNL. Fungal pelleted reactors in wastewater treatment: 
Applications and perspectives. Chem Eng J. 2016;283:553-71. https://doi.org/10.1016/j.cej.2015.07.068 The authors have provided several bioreactor designs for wastewater treatment together with a discussion on main advantages and disadvantages, and influence of several parameters.

74. Lennartsson PR, Erlandsson P, Taherzadeh MJ. Integration of the first and second generation bioethanol processes and the importance of by-products. Bioresour Technol. 2014;165:3-8. https:// doi.org/10.1016/j.biortech.2014.01.127.

75. FazeliNejad S, Brandberg T, Lennartsson PR, Taherzadeh MJ. Inhibitor tolerance: a comparison between Rhizopus sp. and Saccharomyces cerevisiae. Bioresources. 2013;8:5524-35.

76. Lennartsson PR, Ylitervo P, Larsson C, Edebo L, Taherzadeh MJ. Growth tolerance of Zygomycetes Mucor indicus in orange peel hydrolysate without detoxification. Process Biochem. 2012;47: 836-42. https://doi.org/10.1016/j.procbio.2012.02.019.

77. Ferreira JA, Lennartsson PR, Taherzadeh MJ. Production of ethanol and biomass from thin stillage by Neurospora intermedia: a pilot study for process diversification. Eng Life Sci. 2015;15:7519. https://doi.org/10.1002/elsc.201400213.

78. Rajendran K, Rajoli S, Taherzadeh M. Techno-economic analysis of integrating first and second-generation ethanol production using filamentous fungi: an industrial case study. Energies. 2016;9:359. https://doi.org/10.3390/en9050359.

79. Brancoli P, Ferreira JA, Bolton K, Taherzadeh MJ. Changes in carbon footprint when integrating production of filamentous fungi in 1st generation ethanol plants. Bioresour Technol. 2018;249: 1069-73. https://doi.org/10.1016/j.biortech.2017.10.085.

80. Karimi S, Mahboobi Soofiani N, Lundh T, Mahboubi A, Kiessling A, Taherzadeh MJ. Evaluation of filamentous fungal biomass cultivated on vinasse as an alternative nutrient source of fish feed: protein, lipid, and mineral composition. Fermentation. 2019;5:99. https://doi.org/10.3390/ fermentation5040099.

81. Cooper J, Kavanagh J, Razmjou A, Chen V, Leslie G. Treatment and resource recovery options for first and second generation bioethanol spentwash - a review. Chemosphere. 2020;241: 124975. https://doi.org/10.1016/j.chemosphere.2019.124975.

82. Kanaujiya DK, Paul T, Sinharoy A, Pakshirajan K. Biological treatment processes for the removal of organic micropollutants from wastewater: a review. Curr Pollut Rep. 2019;5:112-28. https://doi.org/10.1007/s40726-019-00110-x.

83. Collado S, Oulego P, Suárez-Iglesias O, Díaz M. Leachates and natural organic matter. A review of their biotreatment using fungi. Waste Manag. 2019;96:108-20. https://doi.org/10.1016/j. wasman.2019.07.018.

84. Li C-H, Wong Y-S, Wang H-Y, Tam NF-Y. Anaerobic biodegradation of PAHs in mangrove sediment with amendment of $\mathrm{NaHCO}_{3}$. J Environ Sci. 2015;30:148-56. https://doi.org/10. 1016/j.jes.2014.09.028.

85. Ceci A, Pinzari F, Russo F, Persiani AM, Gadd GM. Roles of saprotrophic fungi in biodegradation or transformation of organic and inorganic pollutants in co-contaminated sites. Appl Microbiol Biotechnol. 2019;103:53-68. https://doi.org/10.1007/s00253018-9451-1.

86. Bilal M, Rasheed T, Iqbal HMN, Yan Y. Peroxidases-assisted removal of environmentally-related hazardous pollutants with reference to the reaction mechanisms of industrial dyes. Sci Total Environ. 2018;644:1-13. https://doi.org/10.1016/j.scitotenv. 2018.06.274.

87. Kadri T, Rouissi T, Kaur Brar S, Cledon M, Sarma S, Verma M. Biodegradation of polycyclic aromatic hydrocarbons (PAHs) by fungal enzymes: A review. J Environ Sci. 2017;51:52-74. https:// doi.org/10.1016/j.jes.2016.08.023 This review provides information on the use of fungal enzymes for bioremediation of PAHs. In addition to transformation pathways, the authors have also reported on the effect of various parameters on enzymatic bioremediation.

88. Alneyadi AH, Rauf MA, Ashraf SS. Oxidoreductases for the remediation of organic pollutants in water - a critical review. Crit Rev Biotechnol. 2018;38:971-88. https://doi.org/10.1080/ 07388551.2017.1423275.

89. Ostrem Loss EM, Yu J-H. Bioremediation and microbial metabolism of benzo(a)pyrene. Mol Microbiol. 2018;109:433-44. https://doi.org/10.1111/mmi.14062.

90.• Mir-Tutusaus JA, Baccar R, Caminal G, Sarrà M. Can white-rot fungi be a real wastewater treatment alternative for organic micropollutants removal? A review. Water Res. 2018;138:13751. https://doi.org/10.1016/j.watres.2018.02.056 In addition to a comprehensive report on the use of white-rot fungi for the bioremediation of various micropollutants, the authors also provide information on parameters influencing competition between white-rot fungi and autochthonous microorganisms.

91. Zhan H, Huang Y, Lin Z, Bhatt P, Chen S. New insights into the microbial degradation and catalytic mechanism of synthetic pyrethroids. Environ Res. 2020;182:109138. https://doi.org/10.1016/j. envres.2020.109138.

92. Kumar D, Pannu R. Perspectives of lindane $(\gamma$ hexachlorocyclohexane) biodegradation from the environment: a review. Bioresour Bioprocess. 2018;5:29. https://doi.org/10. 1186/s40643-018-0213-9.

93. Pratush A, Ye X, Yang Q, Kan J, Peng T, Wang H, et al. Biotransformation strategies for steroid estrogen and androgen pollution. Appl Microbiol Biotechnol. 2020;104:2385-409. https://doi.org/10.1007/s00253-020-10374-9.

94. Aydin S, Karaçay HA, Shahi A, Gökçe S, Ince B, Ince O. Aerobic and anaerobic fungal metabolism and omics insights for increasing polycyclic aromatic hydrocarbons biodegradation. Fungal Biol Rev. 2017;31:61-72. https://doi.org/10.1016/j.fbr.2016.12. 001.

95. Fernández-Luqueño F, Valenzuela-Encinas C, Marsch R, Martínez-Suárez C, Vázquez-Núñez E, Dendooven L. Microbial communities to mitigate contamination of PAHs in soilpossibilities and challenges: a review. Environ Sci Pollut Res. 2011;18:12-30. https://doi.org/10.1007/s11356-010-0371-6.

96. Deshmukh R, Khardenavis AA, Purohit HJ. Diverse metabolic capacities of fungi for bioremediation. Indian J Microbiol. 2016;56:247-64. https://doi.org/10.1007/s12088-016-0584-6.

97. Geissen V, Mol H, Klumpp E, Umlauf G, Nadal M, van der Ploeg $\mathrm{M}$, et al. Emerging pollutants in the environment: a challenge for water resource management. Int Soil Water Conserv Res. 2015;3: 57-65. https://doi.org/10.1016/j.iswcr.2015.03.002.

98. Tortella G, Durán N, Rubilar O, Parada M, Diez MC. Are whiterot fungi a real biotechnological option for the improvement of environmental health? Crit Rev Biotechnol. 2015;35:165-72. https://doi.org/10.3109/07388551.2013.823597.

99. Marco-Urrea E, García-Romera I, Aranda E. Potential of nonligninolytic fungi in bioremediation of chlorinated and polycyclic aromatic hydrocarbons. New Biotechnol. 2015;32:620-8. https:// doi.org/10.1016/j.nbt.2015.01.005.

100. Veiter L, Rajamanickam V, Herwig C. The filamentous fungal pellet-relationship between morphology and productivity. Appl Microbiol Biotechnol. 2018;102:2997-3006. https://doi.org/10. 1007/s00253-018-8818-7.

101. Cairns TC, Zheng X, Zheng P, Sun J, Meyer V. Moulding the mould: understanding and reprogramming filamentous fungal growth and morphogenesis for next generation cell factories. Biotechnol Biofuels. 2019;12:77. https://doi.org/10.1186/ s13068-019-1400-4.

102. Yatmaz E, Karahalil E, Germec M, Ilgin M, Turhan İ. Controlling filamentous fungi morphology with microparticles to enhanced $\beta$ - 
mannanase production. Bioprocess Biosyst Eng. 2016;39:1391-9. https://doi.org/10.1007/s00449-016-1615-8.

103. Antecka A, Bizukojc M, Ledakowicz S. Modern morphological engineering techniques for improving productivity of filamentous fungi in submerged cultures. World J Microbiol Biotechnol. 2016;32:193. https://doi.org/10.1007/s11274-016-2148-7.

104. Bulkan G, Ferreira JA, Taherzadeh MJ. Removal of organic micro-pollutants using filamentous fungi. In: Varjani S, Pandey A, Tyagi RD, Larroche C, Ngo HH, editors. Current Developments in Biotechnology and Bioengineering: Emerging organic micropollutants. Amsterdam: Elsevier; 2020;363-95.

105. Mahboubi A, Ylitervo P, Doyen W, De Wever H, Taherzadeh MJ. Reverse membrane bioreactor: introduction to a new technology for biofuel production. Biotechnol Adv. 2016;34:954-75. https:// doi.org/10.1016/j.biotechadv.2016.05.009.

106. Hofmann U, Fenu A, Beffa T, Beimfohr C, Weemaes M, Yu L, et al. Evaluation of the applicability of the aquatic ascomycete Phomas sp. UHH 5-1-03 for the removal of pharmaceutically active compounds from municipal wastewaters using membrane bioreactors. Eng Life Sci. 2018;18:510-9. https://doi.org/10. 1002/elsc.201800070.

Publisher's Note Springer Nature remains neutral with regard to jurisdictional claims in published maps and institutional affiliations. 